\title{
Status Assessment of Heavy Metals in Water of the Lepenci River Basin, Kosova
}

\author{
Pajtim Bytyçiं ${ }^{2,1}$, Osman Fetoshi ${ }^{*}$, Bujar H. Durmishi ${ }^{3}$, Ferdije Zhushi Etemi' ${ }^{1}$, \\ Hazir Çadraku', Murtezan Ismaili' ${ }^{2}$, Albona Shala Abazi ${ }^{6}$
}

1 Department of Biology, Faculty of Mathematics and Natural Sciences, University of Prishtina "HasanPrishtina", George Bush, Prishtina 10000, Kosova

2 Southeast European University (SEEU), llindenska no 335 Tetova, FYR Macedonia

3 University of Tetova, Faculty of Mathematics and Natural Sciences, Department of Chemistry, Str. Ilindeni nn, 1200 Tetova, FYR Macedonia

${ }^{4}$ University of Applied Sciences, Faculty of Tourism and Environment, Ferizaj, 70000, Kosova

${ }^{5}$ University for Business and Technology, Faculty of Engineering Energy, Kalabira 10000, Pristina, Kosova

${ }^{6}$ University "HaxhiZeka", Faculty of Management in Tourism, Hotels and the Environment, Pejë, Kosova

* Corresponding author e-mail: osmanfetoshi@hotmail.com

\begin{abstract}
Water represents an essential element for life and living things on earth. Aquatic ecosystems play a decisive role in the socio-economic development in urban and rural areas. In recent decades, there has been concern at the global level with regard to the deterioration of aquatic ecosystems due to the pollution, which is a product of mainly anthropogenic activity. Heavy metals pollution is worrisome for the ecological balance of the aquatic environment, affecting a variety of organisms. Therefore, the objective of this paper was to characterize the quality of water in the Lepenci River basin, to express heavy metals concentration, and to determine the surface water quality index in this basin. In order to achieve such an objective, water samples were collected at eight stations for analyzing the concentrations for heavy metals. Heavy metals were determined by means of atomic absorption spectrophotometry. A good correlation was found between $\mathrm{Pb}$ and $\mathrm{Zn}(r=0.84)$, whereas the average negative correlation coefficient was shown between $\mathrm{Mn}$ and $\mathrm{Cr}(r=-0.6513)$. The heavy metals concentrations varied from 0.0092 to $0.1135 \mathrm{mg} / \mathrm{L}$. The mean concentrations of heavy metals found in the river water were in the order of: $\mathrm{Mn}>\mathrm{Fe}>\mathrm{Pb}>\mathrm{Ni}>\mathrm{Cd}>\mathrm{Zn}>\mathrm{Cr}>\mathrm{Cu}$. The Water Quality Index varied from 57 to 81, with the average value of WQI $=68.1250$, which ranks the surface water of this basin as fair. From the results we have concluded that the Lepenci River waters during the monitoring period have had low pollution from heavy metals.
\end{abstract}

Keywords: atomic absorption spectrophotometry, river water, heavy metals, WQI, quality, correlation.

\section{INTRODUCTION}

Water is an essential ingredient for the environment and its quality constitutes an issue of concern. Aquatic ecosystems, such as rivers, play an important role for rural and urban populations in many developing countries. However, in recent years, they have been subjected to various forms of degradation due to the pollution by internal waste, industrial leaks, agricultural waste, and bad fishing practices [Ndimele, 2008]. According to
[Bakare et al., 2003], industrialization and human activities have partially or fully turned the environment into a landfill site. Consequently, many rivers have been polluted and became harmful to the human life and the lives of other living things.

Resistant metals or metalloids with the density greater than $4.5 \mathrm{~g} / \mathrm{cm}^{3}$ are known as heavy metals and include lead, cadmium, mercury, iron, copper, zinc, nickel, and manganese [Anderson, 2003]. Some of them are essential elements without which the biochemical processes in living or- 
ganisms would not be possible; however, when they exceed normal concentrations, they become harmful to organisms. Heavy metals pollution can cause disturbing effects on the ecological balance of the aquatic environment and affect a variety of organisms. This is of particular importance in ecotoxicology, as heavy metals are highly persistent and have the tendency to bioaccumulate and concentrate in the food chain; at higher concentrations, they become toxic to organisms. Heavy metal pollution in water can be monitored through measuring their concentrations [Senarathne and Pathiratne, 2007].

Heavy metals are of special importance to surface water pollution. Certain metals are useful, while others are harmful and toxic. Some metals, such as $\mathrm{Ca}$ and $\mathrm{Mg}$ are essential chemical elements, whereas other metals adversely affect water consumers. It was proven that $\mathrm{Pb}, \mathrm{Hg}$, and As are strong, toxic pollutants [BožoDalmacija, 2001]. The toxicity of heavy metals depends on the type of metal and compound, the amount that reaches the body and the duration of metal reaction. This group includes $\mathrm{Hg}, \mathrm{Pb}, \mathrm{Cd}, \mathrm{Cr}$, $\mathrm{Cu}, \mathrm{Ni}, \mathrm{As}$ and $\mathrm{Zn}$.

Heavy metals are of particular importance for the environment, as they exhibit toxicity and persistence and are known for their bioaccumulation in food chains [WHO, 2000]. They cause adverse effects on plants and animals, and are dangerous to the human health. It is known that metal toxicity occurs mainly due to the presence of free metal ions.

Water quality directly affects the health of living things, reflecting the level of contamination of the aquatic ecosystem. Water quality monitoring is an important component of water management, for which the data analysis is needed to identify and characterize water quality issues. Assessment is the process through which water quality data is transformed into information. The information acquired from the monitoring is essential for assessing the water quality. Monitoring can also verify the water contamination based on which a corrective action can be undertaken. Surface waters should be monitored microbiologically, chemically, physically, and radiologicallyin order to determine the presence of pollutants. Therefore, effective monitoring and assessment of surface water quality are crucial to protecting the aquatic life and human health since wastewater consumption is one of the major causes of diseases. Thus, with a preventive approach, the quality of water can be managed.
Water quality assessment can be carried out in various ways. In 1965, Horton was the first to formulate a water quality index which was then used by many researchers for different types of water. A very powerful tool to this end is the Water Quality Index (WQI). WQI serves to sum up large amounts of water quality data in simple categories (good, bad) for management and public reporting [Durmishi et al., 2012]. Researchers use different types of indices. The index aims at transforming numerous water quality data to simple, understandable, and usable information for the public. WQI represents a number from 0 to 100 where a higher value means better water quality and vice versa. The aim of the paper was to assess the level of heavy metal concentrations in water that will focus on the pollution status of the Lepenci river.

\section{MATERIALS AND METHODS}

\section{Study area}

The Lepenci river is located in the southeast of the Republic of Kosova. It originates in the Oshlak mountains at an altitude of $2212 \mathrm{~m}$; its total length is $50 \mathrm{~km}$ and has a slope of $2.1 \%$. Annual average flow is $8.4 \mathrm{~m}^{3} / \mathrm{s}$. The minimum flow of the river Lepenci $1.8 \mathrm{~m}^{3} / \mathrm{s}$, as shown at the Hydrometric Station in Hani i Elezit [MESP, 2010].

The Lepenci river represents the main catchment area in the southeastern region of Kosova. It has an area of $652 \mathrm{~km}^{2}$ covering $5.98 \%$ of the territory of the Republic of Kosova. The area where the river Lepenci flows is characterized by the continental and mountain climate. The average annual rain is $861.4 \mathrm{~mm}$, while the average annual temperature is $10.2^{\circ} \mathrm{C}$ [Kaçanik, 2011].

For realization of this work, the water samples were taken in spring, summer and autumn of 2017 in eight sampling points along the Lepenci river flow that included upper, middle and downstream. The sampling points were: SP1 (Prevallë), SP2 (Jezerc), SP3 (Brod), SP4 (Runjevë), SP5 (Nikë), SP6 (Gërlicë), SP7 (Kaçanik) and SP8 (Hani iElezit). The sample bottles were labeled with the date and source of sampling; they were kept in refrigerators at $4{ }^{\circ} \mathrm{C}$ and transported under the appropriate procedure 21 .

The analysis of water samples taken in river Lepenci was performed in the laboratory of the Kosova Hydro Meteorological Institute (KHMI). Heavy metals were determined by means of 


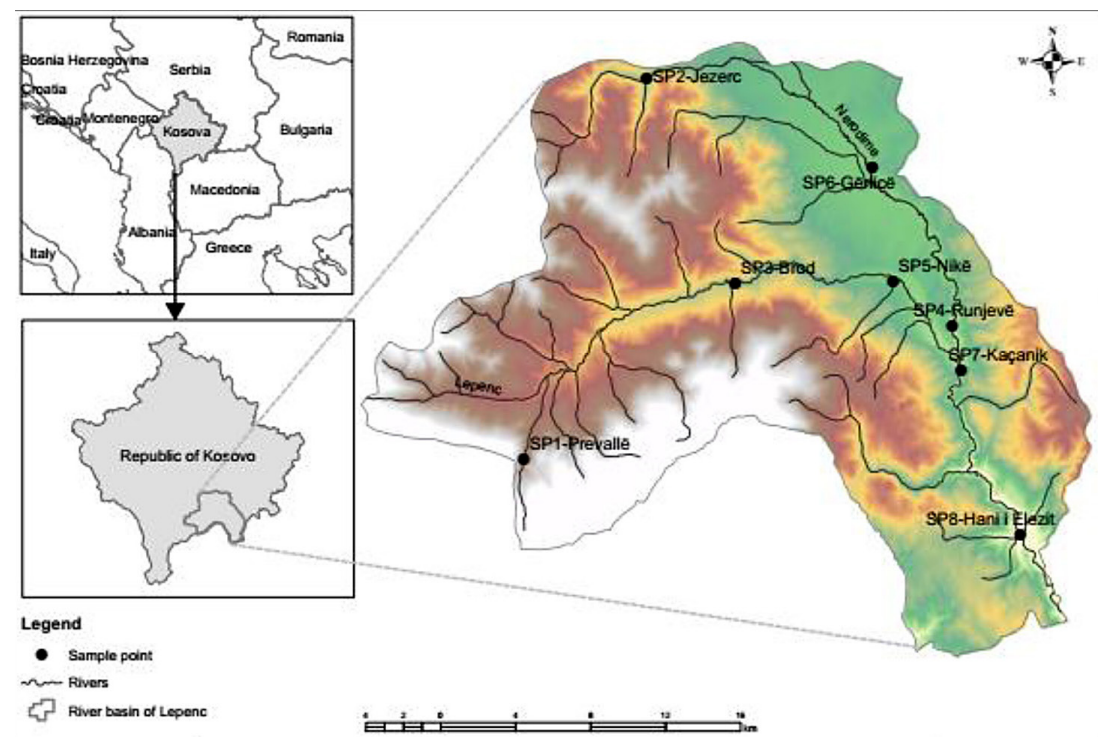

Figure 1. Map of monitoring stations

Atomic absorption Spectrophotometer of American label Perkin Elmer, type Analyst 400. The methods applied to these devices conform to standard methods such as: DIN, ISO and EN. Statistical calculations in this paper were conducted with Excel software, where the data is input and mathematical equations integrated in this program are extracted values: minimal, maximum, average, standard deviation and variation coefficient for the parameters measured for each sampling station that were shown graphically in the works. Data interpretations are performed based on the data obtained in the laboratory, their processing and comparison with the standards.

\section{Canadian Water Quality Index}

In order to assess the drinking water quality we have widely used the Water Quality Index (WQI) developed by the Canadian Council of Ministers of the Environment [CCME, 2001]. WQI consists of three measures of variance from selected drinking water quality objectives. These are: scope (F1), frequency (F2), and amplitude (F3).

The scope represents the water quality of the legal norm that does not meet the objectives during the period of interest and is expressed by the equation:

$$
F_{1}=\left(\frac{\text { Number of failed variables }}{\text { Total number of variables }}\right)
$$

Frequency represents the percentage of individual tests that do not meet the objectives. It is expressed with the following equation:

$$
F_{2}=\left(\frac{\text { Number of failed tests }}{\text { Total number of tests }}\right) \cdot 100
$$

Amplitude represents the amount by which failed tests do not meet the objectives. It is expressed with the following equation:

$$
F_{3}=\left(\frac{n s e}{0.01 \cdot n s e+0.01}\right)
$$

where nse shows the normalized sum of excursions, that is, the summation by which individual tests do not meet the objectives.

WQI is then calculated according to the following equation:

$$
W Q I=100-\left(\frac{\sqrt{{F_{1}}^{2}+{F_{2}}^{2}+{F_{3}}^{2}}}{1.732}\right)
$$

The number 1.732 normalizes the resulting values to an extent between 0 and 100, where 0 represents the worst water quality and 100 represents the best water quality. Water quality is then ranked in one of the following six categories (Table 1).

\section{RESULTS AND DISCUSSION}

The results of heavy metals concentrations measured in the Lepenci river water at different stations are given in Table 2 and Figures 2-9. 
Table 1. Categorization of water quality according to WQI values and description.

\begin{tabular}{|l|c|l|}
\hline \multicolumn{1}{|c|}{ Class } & WQI value & \multicolumn{1}{c|}{ Description } \\
\hline Excellent & $95-100$ & $\begin{array}{l}\text { Water quality is protected with a virtual absence of impairment; conditions are very } \\
\text { close to pristine levels. These index values can only be obtained if all measurements } \\
\text { meet recommended guidelines virtually all the time. }\end{array}$ \\
\hline Very good & $89-94$ & $\begin{array}{l}\text { Water quality is protected with a slight presence of impairment; conditions are close } \\
\text { to pristine levels. }\end{array}$ \\
\hline Good & $80-88$ & $\begin{array}{l}\text { Water quality is protected with only a minor degree of impairment; conditions rarely } \\
\text { depart from desirable levels. }\end{array}$ \\
\hline Fair & $65-79$ & $\begin{array}{l}\text { Water quality is usually protected but occasionally impaired; conditions sometimes } \\
\text { depart from desirable levels. }\end{array}$ \\
\hline Marginal & $45-64$ & Water quality is frequentlyimpaired; conditions often depart from desirable levels. \\
\hline Poor & $0-44$ & $\begin{array}{l}\text { Water quality is almost always impaired; conditions usually depart from desirable } \\
\text { levels }\end{array}$ \\
\hline
\end{tabular}

\section{Cromium ( $\left.3^{+}\right)$}

$\mathrm{Cr}$ is an essential micronutrient for animals and plants. It is considered as a relative biological and pollution significance element [Rajappa et al., 2010]. Generally, the natural content of chromium in water is very low except for the regions with substantial chromium deposits. The concentration of $\mathrm{Cr}$ can result from industrial and mining processes. Fish are usually more resistant to $\mathrm{Cr}$ than other aquatic organisms, but they can be affected sub-lethally when the concentration increases [Krishna et al., 2014].
The results from experimental measurements for the $\mathrm{Cr}^{3+}$ are shown in Table 2 and Figure 2. The recommended value for the $\mathrm{Cr}^{3+}$ according to the Romanian standards for assessing the ecological status of surface water (GD161) is $0.025->0.250 \mathrm{mg} / \mathrm{L}$. During the three-season study, the $\mathrm{Cr}^{3+}$ concentration varied from 0.0110 to $0.0360 \mathrm{mg} / \mathrm{L}$. The lowest value was measured at SP3 and SP4 stations in spring and fall, whereas the highest value was measured at SP5 station in spring. The average values in spring, summer, and fall were $0.023,0.035$, and $0.012 \mathrm{mg} / \mathrm{L}$ respectively, whereas the three-season average with

Table 2. Results of metal concentration and statistics

\begin{tabular}{|c|c|c|c|c|c|c|c|c|c|c|c|c|c|c|c|}
\hline & \multicolumn{2}{|c|}{$\begin{array}{l}\text { Heavy metals, } \\
\mathrm{mg} / \mathrm{L}\end{array}$} & Prevallë & Jezerc & Brod & Runjevë & Nikë & Gërlicë & Kaçanik & $\begin{array}{l}\text { Hani } \\
\text { i Elezit }\end{array}$ & Max & Min & Aver & SD & $\mathrm{Cv}$ \\
\hline SP & Chromium & $\mathrm{Cr}^{3+}$ & $<0.003$ & $<0.003$ & 0.011 & 0.016 & 0.036 & $<0.003$ & $<0.003$ & 0.029 & 0.036 & 0.011 & 0.023 & 0.011 & 0.49 \\
\hline SA & Chromium & $\mathrm{Cr}^{3+}$ & $<0.003$ & 0.035 & $<0.003$ & $<0.003$ & $<0.003$ & $<0.003$ & $<0.003$ & $<0.003$ & 0.035 & 0.035 & 0.035 & 0 & 0 \\
\hline$A U$ & Chromium & $\mathrm{Cr}^{3+}$ & $<0.003$ & $<0.003$ & 0.011 & 0.011 & $<0.003$ & $<0.003$ & 0.018 & 0.008 & 0.018 & 0.008 & 0.012 & 0.004 & 0.34 \\
\hline SP & Cadmium & $\mathrm{Cd}^{2+}$ & $<0.001$ & $<0.001$ & $<0.001$ & 0.084 & 0.042 & 0.104 & 0.082 & 0.089 & 0.104 & 0.042 & 0.078 & 0.023 & 0.29 \\
\hline SA & Cadmium & $\mathrm{Cd}^{2+}$ & 0.023 & 0.031 & 0.047 & $<0.001$ & 0.075 & 0.053 & $<0.001$ & 0.084 & 0.084 & 0.023 & 0.052 & 0.023 & 0.45 \\
\hline$A U$ & Cadmium & $\mathrm{Cd}^{2+}$ & $<0.001$ & $<0.001$ & 0.015 & 0.005 & 0.033 & 0.009 & $<0.001$ & $<0.001$ & 0.033 & 0.005 & 0.016 & 0.012 & 0.74 \\
\hline SP & Nickel & $\mathrm{Ni}^{2+}$ & 0.014 & 0.015 & 0.068 & 0.053 & 0.018 & 0.155 & 0.119 & 0.047 & 0.155 & 0.014 & 0.065 & 0.051 & 0.78 \\
\hline SA & Nickel & $\mathrm{Ni}^{2+}$ & 0.069 & 0.066 & 0.027 & 0.025 & 0.118 & $<0.006$ & $<0.006$ & $<0.006$ & 0.118 & 0.025 & 0.064 & 0.038 & 0.59 \\
\hline$A U$ & Nickel & $\mathrm{Ni}^{2+}$ & 0.054 & $<0.006$ & $<0.006$ & 0.002 & 0.012 & $<0.006$ & 0.045 & 0.035 & 0.054 & 0.002 & 0.029 & 0.022 & 0.75 \\
\hline SP & Zinc & $\mathrm{Zn}^{2+}$ & 0.005 & 0.007 & 0.01 & 0.055 & $<0.0003$ & $<0.0003$ & 0.075 & 0.008 & 0.075 & 0.005 & 0.03 & 0.036 & 1.01 \\
\hline SA & Zinc & $\mathrm{Zn}^{2+}$ & 0.078 & 0.03 & 0.018 & 0.035 & 0.031 & 0.04 & 0.036 & 0.011 & 0.078 & 0.011 & 0.036 & 0.019 & 0.54 \\
\hline$A U$ & Zinc & $\mathrm{Zn}^{2+}$ & 0.014 & 0.050 & 0.026 & 0.003 & 0.002 & 0.038 & 0.031 & 0.168 & 0.168 & 0.002 & 0.05 & 0.053 & 1.07 \\
\hline SP & Manganese & $\mathrm{Mn}^{2+}$ & $<0.002$ & $<0.002$ & 0.136 & 0.285 & 0.117 & 0.151 & 0.242 & 0.433 & 0.433 & 0.117 & 0.23 & 0.12 & 0.50 \\
\hline SA & Manganese & $\mathrm{Mn}^{2+}$ & 0.088 & 0.106 & 0.094 & 0.095 & 0.058 & 0.460 & 0.053 & 0.115 & 0.46 & 0.053 & 0.15 & 0.13 & 0.84 \\
\hline$A U$ & Manganese & $\mathrm{Mn}^{2+}$ & 3.736 & 0.12 & 1.502 & 1.602 & 0.146 & 0.365 & 0.207 & 0.106 & 3.736 & 0.106 & 1.16 & 1.27 & 1.09 \\
\hline SP & Copper & $\mathrm{Cu}^{2+}$ & 0.021 & 0.023 & 0.037 & $<0.002$ & 0.001 & $<0.002$ & 0.009 & 0.038 & 0.038 & 0.001 & 0.021 & -0.015 & -0.7 \\
\hline SA & Copper & $\mathrm{Cu}^{2+}$ & $<0.002$ & $<0.002$ & $<0.002$ & 0.001 & $<0.002$ & 0.010 & $<0.002$ & $<0.002$ & 0.01 & 0.001 & 0.005 & 0.006 & 1.15 \\
\hline $\mathrm{AU}$ & Copper & $\mathrm{Cu}^{2+}$ & $<0.002$ & $<0.002$ & $<0.002$ & $<0.002$ & $<0.002$ & $<0.002$ & $<0.002$ & $<0.002$ & 0 & 0 & 0 & 0 & 0 \\
\hline SP & Iron & $\mathrm{Fe}^{2+}$ & 0.115 & 0.12 & 0.401 & 0.154 & 0.332 & 0.065 & 0.046 & 0.243 & 0.401 & 0.046 & 0.192 & 0.12 & 0.66 \\
\hline SA & Iron & $\mathrm{Fe}^{2+}$ & 0.003 & $<0.002$ & $<0.002$ & 0.229 & 0.034 & 0.175 & 0.081 & $<0.002$ & 0.229 & 0.003 & 0.108 & 0.09 & 0.88 \\
\hline$A U$ & Iron & $\mathrm{Fe}^{2+}$ & $<0.002$ & 0.03 & 0.008 & 0.112 & 0.075 & 0.128 & 0.199 & 0.165 & 0.199 & 0.008 & 0.103 & 0.06 & 0.67 \\
\hline SP & Lead & $\mathrm{Pb}^{2+}$ & 0.047 & 0.053 & $<0.002$ & 0.181 & $<0.002$ & 0.295 & 0.341 & 0.385 & 0.0385 & 0.047 & 0.21 & 0.14 & 0.67 \\
\hline SA & Lead & $\mathrm{Pb}^{2+}$ & $<0.002$ & $<0.002$ & $<0.002$ & $<0.002$ & $<0.002$ & $<0.002$ & $<0.002$ & $<0.002$ & 0 & 0 & 0 & 0 & 0 \\
\hline$A U$ & Lead & $\mathrm{Pb}^{2+}$ & $<0.002$ & 0.007 & 0.005 & $<0.002$ & $<0.002$ & 0.018 & 0.031 & 0.097 & 0.097 & 0.005 & 0.03 & 0.03 & 1.02 \\
\hline
\end{tabular}




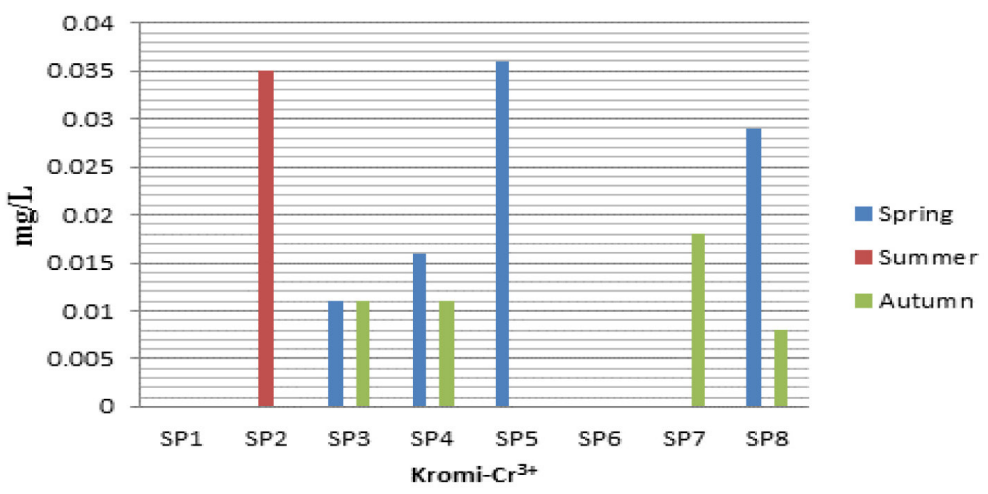

Figure 2. Variation of $\mathrm{Cr}$ values in water of Lepenci river

the standard deviation was $0.0233 \pm 0.005 \mathrm{mg} / \mathrm{L}$. The $\mathrm{Cr}^{3+}$ average concentrations at SP1-SP8 stations were $0.0030,0.0137,0.0083,0.0100$, $0.0140,0.0030,0.0080$, and $0.0133 \mathrm{mg} / \mathrm{L}$, respectively. In spring, the SP3 station showed the minimum value of $0.0110 \mathrm{mg} / \mathrm{L}$, whereas the $\mathrm{SP} 5 \mathrm{sta}-$ tion showed the maximum value of $0.0360 \mathrm{mg} / \mathrm{L}$. In summer, the SP2 station showed the minimum value of $0.0350 \mathrm{mg} / \mathrm{L}$, whereas the SP2 station showed the maximum value of $0.0350 \mathrm{mg} / \mathrm{L}$. In fall, SP7 and SP8 stations showed the minimum value of $0.0080 \mathrm{mg} / \mathrm{L}$, whereas the SP7 station showed the maximum value of $0.0180 \mathrm{mg} / \mathrm{L}$. The measurements for the $\mathrm{Cr}^{3+}$ in the water of Lepenc River basin were found to be within the minimum values which, if compared to the GD161 standards, were within the allowed limits, thus ranking the water of this river in the first class.

\section{Cadmium $\left(\mathrm{Cd}^{2+}\right)$}

$\mathrm{Cd}$ as pollutants in the water can reach from industrial discharges and waste ore. It is widely used in galvanization and production of batteries. $\mathrm{Cd}$ is chemically similar to $\mathrm{Zn}$ and found in water in the oxidation form +2 . It occurs naturally as $\mathrm{CdS}$ and followed minerals of $\mathrm{Pb}$ and $\mathrm{Zn}$. Food is the main source of $\mathrm{Cd}$ poisoning. The effects of acute $\mathrm{Cd}$ poisoning in humans are very serious, including hypertension, kidney damage, causing potential prostate cancer, etc. [Durmishi et al., 2016]. The physiological effects of Zn with Cd replacement in some enzymatic reactions hampered the normal functioning of enzymes. The toxic effect of $\mathrm{Cd}$ in water decreases with the increasing hardness of the water, due to rising water carbonates content. Heavy metal carbonates are less soluble in water and so a part of dissolved $\mathrm{Cd}$ is removed . It is a non-essential element, known to have a toxic potential. $\mathrm{Cd}$ is highly toxic and re- sponsible for several cases of poisoning through food. Small quantities of Cd cause adverse changes in the arteries of human kidney. It replaces $\mathrm{Zn}$ biochemically and causes hypertension as well as kidney damage. It interferes with enzymes and causes a painful disease called Itai-itai [Rajappaet al., 2010]. High concentration of Cd occurs at neutral and alkali $\mathrm{pH}$.

The results from experimental measurements for the $\mathrm{Cd}^{2+}$ are shown in Table 2 and Figure 3. According to the Romanian standards for assessing the ecological status of surface water (GD161), the recommended value for the $\mathrm{Cd}^{2+}$ is $0.0005-$ $>0.005 \mathrm{mg} / \mathrm{L}$. During the three-season study, the $\mathrm{Cd}^{2+}$ concentration varied from 0.0050 to 0.0840 $\mathrm{mg} / \mathrm{L}$. The lowest value was measured at SP4 station in fall, whereas the highest value was measured at SP8 station in summer. The average values in spring, summer, and fall were 0.0780, 0.0520 , and $0.0160 \mathrm{mg} / \mathrm{L}$ respectively, whereas the three-season average with the standard deviation was $0.0487 \pm 0.0193 \mathrm{mg} / \mathrm{L}$. The $\mathrm{Cd}^{2+}$ average concentrations at SP1-SP8 stations were 0.0083, $0.0110,0.0210,0.0300,0.0500,0.0553,0.0280$ and $0.0580 \mathrm{mg} / \mathrm{L}$ respectively. In spring, the SP5 station showed the minimum value of 0.0420 $\mathrm{mg} / \mathrm{L}$, whereas the SP6 station showed the maximum value of $0.1040 \mathrm{mg} / \mathrm{L}$. In spring, the SP1, SP2, and SP3 stations showed the values below detection levels; water values at SP4, SP6, SP7, and SP8 stations, based on GD161 standards, resulted in classification to the fifth class, whereas the water at SP5 station belonged to the third class. In summer, the SP1 station showed the minimum value of $0.0230 \mathrm{mg} / \mathrm{L}$, whereas the SP8 station showed the maximum value of $0.0840 \mathrm{mg} / \mathrm{L}$. In summer, the analyzed values at SP4 and SP7 stations were below the detection levels; the water values at the SP1, SP2, and SP3 stations belonged to the third class, whereas $\mathrm{Cd}^{2+}$ values of water at SP5, SP6, 
and SP8 stations were categorized into the fifth category. In fall, the SP4 station showed the minimum value of $0.0050 \mathrm{mg} / \mathrm{L}$, whereas the SP5 station showed the maximum value of $0.0330 \mathrm{mg} / \mathrm{L}$. In fall, the $\mathrm{Cd}^{2+}$ values at SP1, SP2, SP7, and SP8 stations were under the detection levels; the water at the SP3, SP4, and SP6 stations belonged to the fifth category, whereas the water of the SP5 station belonged to the third category. According to the seasonal average at all stations, the water belonged to the fifth category.

\section{Nickel $\left(\mathrm{Ni}^{2+}\right)$}

$\mathrm{Ni}$ is an essential trace metal for several animal species, micro-organisms and plants; therefore, either deficiency or toxicity symptoms canoccur when, too little or too much Ni is taken up, respectively. Although a number of cellular effects of Ni have been documented, a deficiency state in humans has not been described [Scoott-Fordsmand, 1997]. Ni and its compounds have many industrial and commercial uses, and the progress of industrialization has led to an increased emission of pollutants into ecosystems. Although $\mathrm{Ni}$ is omnipresent and vital for the function of many organisms, concentrations in some areas from both the anthropogenic release and naturally varying levels may be toxic to living organisms [Diagomanol et al., 2004]. Ni cause toxic effects in the respiratory tract and immune system. The exposure of the general population to Ni mainly concernedthe oral intake, primarily through water and food. It is also known to affect non-occupationally exposed individuals, especially those handling stainless steel and nickel-plated articles of everyday use, because nickel is a common sensitizing agent with a high prevalence of allergic contact dermatitis [Kitaura et al., 2003].
The results from the experimental measurements for the $\mathrm{Ni}^{2+}$ are shown in Table 2 and Figure 4. According to the Romanian standard for assessing the ecological status of surface water (GD161), the recommended value for the $\mathrm{Ni}^{2+}$ is $0.01->0.1 \mathrm{mg} / \mathrm{L}$. During the three-season study, the $\mathrm{Ni}^{2+}$ concentration varied from 0.0020 to $0.01550 \mathrm{mg} / \mathrm{L}$. The lowest value was measured at SP4 station in fall, whereas the highest value was measured at SP6 station in spring. Average values in spring, summer, and fall were 0.065 , 0.064 , and $0.029 \mathrm{mg} / \mathrm{L}$ respectively, whereas the three-season average with the standard deviation was $0.0527 \pm 0.0370 \mathrm{mg} / \mathrm{L}$. The average concentrations values of the $\mathrm{Ni}^{2+}$ at SP1-SP8 stations were $0.0457,0.0290,0.0337,0.0267,0.0493$, $0.0557,0.0567$, and $0.0293 \mathrm{mg} / \mathrm{L}$, respectively. In spring, the SP1 station showed the minimum value of $0.0140 \mathrm{mg} / \mathrm{L}$, whereas the SP6 station showed the maximum value of $0.1550 \mathrm{mg} / \mathrm{L}$. In summer, the SP3 station showed the minimum value of $0.0250 \mathrm{mg} / \mathrm{L}$, whereas the $\mathrm{SP} 5$ station showed the maximum value of $0.1180 \mathrm{mg} / \mathrm{L}$. In fall the SP4 station showed the minimum value of $0.0020 \mathrm{mg} / \mathrm{L}$, whereas the SP7 station showed the maximum value of $0.0540 \mathrm{mg} / \mathrm{L}$. The measurements for the $\mathrm{Ni}^{2+}$ in the water of Lepenc River basin were found to be within the allowed recommended values of GD161 standards, thus ranking the water of Lepenci river in the first class.

\section{Zinc $\left(Z^{2+}\right)$}

$\mathrm{Zn}$ is found in natural waters in larger quantities compared with $\mathrm{Cu}, \mathrm{Pb}, \mathrm{Cd}$ and $\mathrm{Hg}$, so the industrial discharge waters containing high concentrations of it. $\mathrm{Zn}$ is an essential element for the life of animal and human beings. It is found in virtually all food and potable water in the form

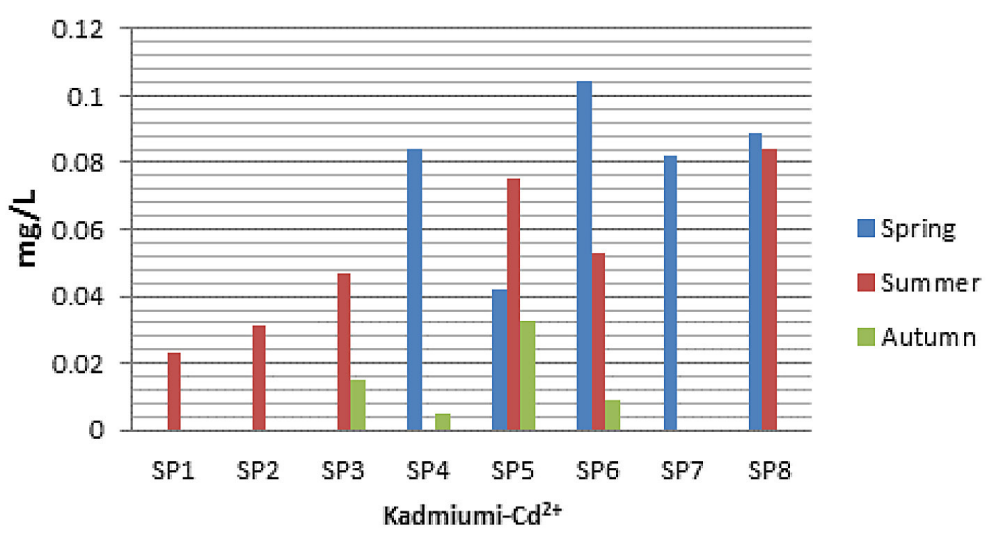

Figure 3. Variation of $\mathrm{Cd}$ values in water of Lepenci river 


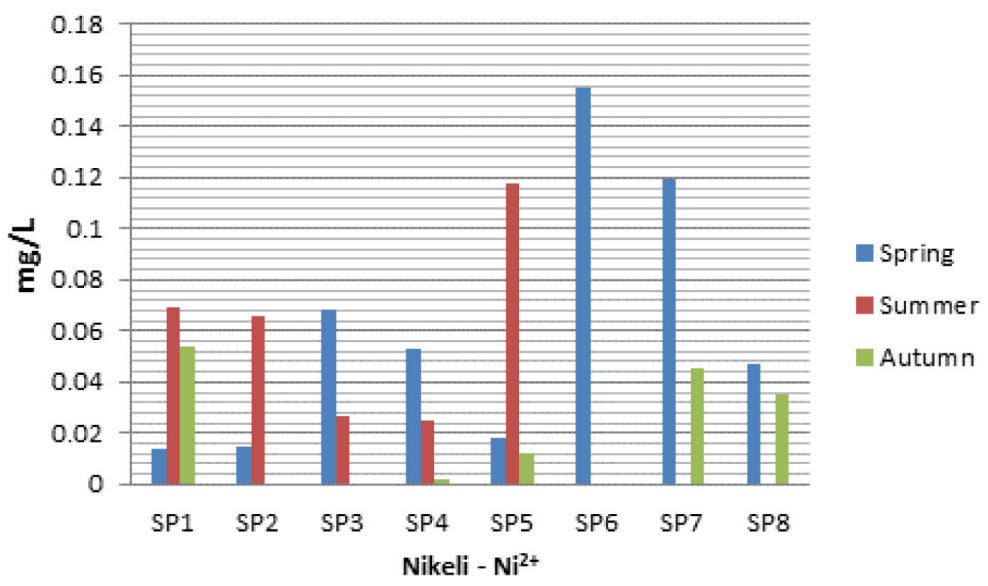

Figure 4. Variation of Ni values in water of Lepenci river

of salts or organic complexes [WHO, 2011]. The main sources of $\mathrm{Zn}$ pollution in the environment are zinc fertilizers, sewage sludge, and mining. Urban runoff, mine drainage, and municipal sewages are the more concentrated sources of zinc in water [Damodharan, 2013]. Zn is not accumulated in the body and it is activating enzymes. It affects bone growth, development and functioning of reproductive organs, etc. There are rare cases of $\mathrm{Zn}$ poisoning. Its action in the aquatic fauna depends on the hardness of water, saturated with oxygen and temperature. Salts of alkaline-earth elements reduce the toxicity of $\mathrm{Zn}$, while increasing the temperature, whereas the lowering the concentration of dissolved oxygen increases the toxicity of $\mathrm{Zn}$. It plays a vital role in the physiological and metabolic processes of many organisms. Other clinical signs of $\mathrm{Zn}$ toxicity have been reported as diarrhea, bloody urine, liver failure, kidney failure and anemia [Duruibe et al., 2007].

The results from experimental measurements for the $\mathrm{Zn}^{2+}$ are shown in Table 2 and Figure 5. Ac- cording to the Romanian standards for assessing the ecological status of surface water (GD161), the recommended value for $\mathrm{Zn}^{2+}$ is $0.1->1 \mathrm{mg} / \mathrm{L}$. During the three-season study, the $\mathrm{Zn}^{2+}$ concentration varied from 0.0020 to $0.01680 \mathrm{mg} / \mathrm{L}$. The lowest value was measured at SP5 station in fall, whereas the highest value was measured at SP8 station in fall. The average values in spring, summer, and fall were $0.030,0.036$, and $0.005 \mathrm{mg} / \mathrm{L}$ respectively, whereas the three-season average with the standard deviation was $0.0387 \pm 0.0360$ $\mathrm{mg} / \mathrm{L}$. The average concentrations values of the $\mathrm{Zn}^{2+}$ at SP1-SP8 stations were 0.0323, 0.0290, $0.0180,0.0310,0.0111,0.0261,0.0473$, and $0.0623 \mathrm{mg} / \mathrm{L}$ respectively. In spring, the SP1 station showed the minimum value of $0.0050 \mathrm{mg} / \mathrm{L}$, whereas the SP7 station showed the maximum value of $0.0750 \mathrm{mg} / \mathrm{L}$. In summer, the SP8 station showed a minimum value of $0.0110 \mathrm{mg} / \mathrm{L}$, whereas the SP1 station showed the maximum value of $0.0780 \mathrm{mg} / \mathrm{L}$. In fall, the SP5 station showed the minimum value of $0.0020 \mathrm{mg} / \mathrm{L}$, whereas the SP8

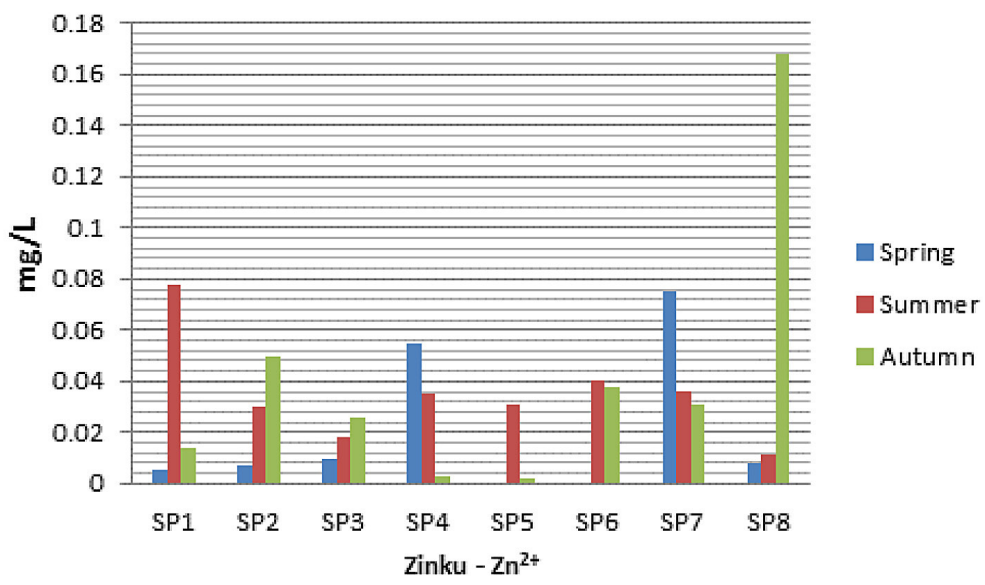

Figure 5. Variation of $\mathrm{Zn}$ values in water of Lepenci river 
station showed the maximum value of 0.1680 $\mathrm{mg} / \mathrm{L}$. On the basis of the GD161 standards, the levels of $\mathrm{Zn}^{2+}$ in the water of Lepenc River basin during the three seasons were found to be within the recommended values, thus ranking the water of this river in the first class.

\section{Manganese $\left(\mathrm{Mn}^{2+}\right)$}

$\mathrm{Mn}$ is present in over 100 common salts and mineral complexes that are widely distributed in rocks, in soils and on the floors of lakes and oceans [Damodharan, 2013]. These Mn minerals include sulfides, oxides, carbonates, silicates, phosphates, arsenates, tungstates, and borates. However, the most important $\mathrm{Mn}$ mineral is the native black manganese oxide, pyrolusite $\left(\mathrm{MnO}_{2}\right)$. $\mathrm{Mn}$ is used for production of ferromanganese steels, electrolytic manganese dioxide for use in batteries, alloys, catalysts, antiknock agents, pigments, dryers, wood preservatives and coating welding rods [Bradi, 2005]. It is also used as an oxidant for cleaning, bleaching and disinfection (as potassium permanganate) and as an ingredient of various products [WHO, 2011]. Mn is an essential micronutrient present in all living organisms, because it functions as a co factor for many enzyme acticities [Suresh et al., 1999]. Mn is a metal with low toxicity but has a considerable biological significance and seems to accumulate in fish [Kumar et al., 2011]. According to [Krishna et al., 2014], high Mn concentration interferes with the central nervous system of vertebrates; hence, the consumption of Mn contaminated fish potentially resulting in health risks to the consumers is a matter of concern. High concentration of Mn causes liver cirrhosis and also produces a poisoning called Manganese or Parkinson disease [Bradi, 2005].
The results from experimental measurements for the $\mathrm{Mn}^{2+}$ are shown in Table 2 and Fig. 6. According to the Romanian standards for assessing the ecological status of surface water (GD161), the recommended value for the $\mathrm{Mn}^{2+}$ is $0.05->1$ $\mathrm{mg} / \mathrm{L}$. During the three-season study, the $\mathrm{Mn}^{2+}$ concentration varied from 0.0530 to $3.7360 \mathrm{mg} / \mathrm{L}$. The lowest value was measured at SP7 station in summer, whereas the highest value was measured at SP1 station in fall. The average values in spring, summer, and fall were $0.2300,0.1500$, and $1.1600 \mathrm{mg} / \mathrm{L}$ respectively, whereas the threeseason average with the standard deviation was $0.5133 \pm 0.5067 \mathrm{mg} / \mathrm{L}$. The average concentrations of $\mathrm{Mn}^{2+}$ at SP1-SP8 stations were 1.2753, $0.0760,0.5773,0.6607,0.1070,0.3253,0.1673$, and $0.2180 \mathrm{mg} / \mathrm{L}$ respectively. In spring, SP5 station showed the minimum value of $0.1170 \mathrm{mg} / \mathrm{L}$, whereas the SP8 station showed the maximum value of $0.4330 \mathrm{mg} / \mathrm{L}$. The $\mathrm{Mn}^{2+}$ concentration in the river waters at SP1 and SP2 stations was under the detection levels; water at SP3, SP5 and SP6 stations belonged to the second class, whereas the SP4, SP7, and SP8 stations belonged to the fifth class. In summer, the SP7 station showed the minimum value of $0.0530 \mathrm{mg} / \mathrm{L}$, whereas the SP6 station showed the maximum value of 0.4600 $\mathrm{mg} / \mathrm{L}$. Compared to GD 161 standards, the water at SP1, SP2, SP3, SP4, SP5, SP7, and SP8 stations belonged to the first class, whereas the water at SP6 station belonged to the fifth class. In fall, the SP8 station showed the minimum value of 0.1060 $\mathrm{mg} / \mathrm{L}$, whereas the SP1 station showed the maximum value of $3.7360 \mathrm{mg} / \mathrm{L}$. Compared to GD 161 standards, the water at SP1 and SP7 stations belonged to the fifth class, the water at SP2 and SP5 stations belonged to the first class, and the water at SP3 and SP4 stations belonged to the third class.

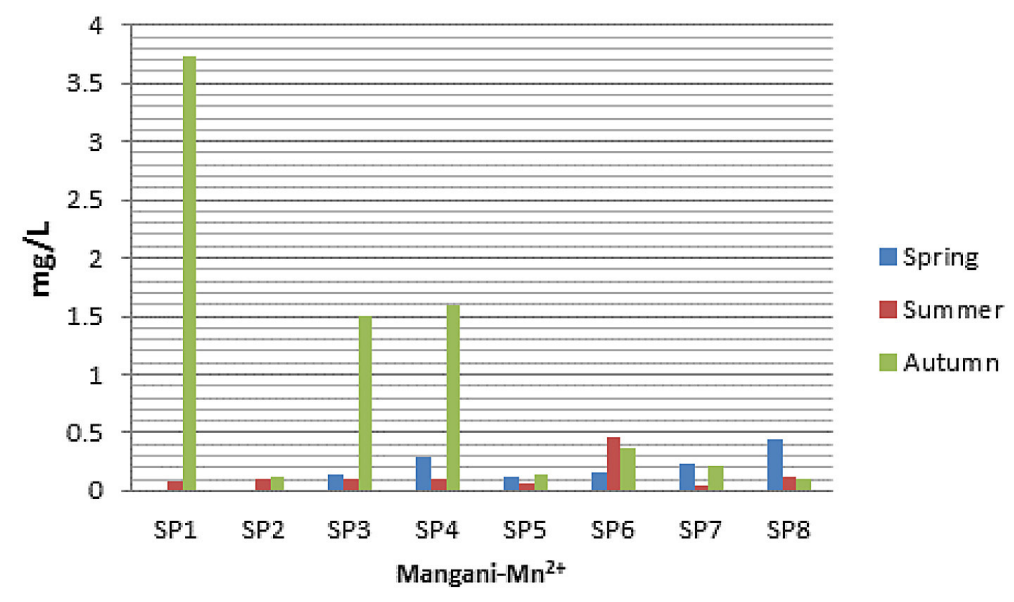

Figure 6. Variation of Mn values in water of Lepenci river 


\section{Copper $\left(\mathrm{Cu}^{2+}\right)$}

$\mathrm{Cu}$ is an essential constituent of living systems and is widely distributed metal in nature. $\mathrm{Cu}$ can exist in aquatic environment in three forms, namely soluble, colloidal and particulate. $\mathrm{Cu}$ is a rare ingredient of natural waters. It is used in $\mathrm{Cu}$ pipes or dosing tanks with copper sulphate(II), which is used to prevent the growth of algae. It was proven that $\mathrm{Cu}$ is toxic to fish and other aquatic creatures, in those concentrations that do not pose a risk to man. It is known that an ion of $\mathrm{Cu}(\mathrm{II})$ is mainly poisonous chemical element. Copper is important for human life and other living things, so it plays an important role in metabolic processes, affecting a number of enzymes and hemoglobin synthesis. The toxicity of $\mathrm{Cu}$ in water depends on the alkalinity, $\mathrm{pH}$ value, the content of organic substances, etc. With the increase of these parameters, the concentration of ions of $\mathrm{Cu}$ (II) decreases in addition to the $\mathrm{Cu}$ toxicity to aquatic systems. High doses may also cause anaemia, liver and kidney damage, stomach and intestinal irritation [Tirkey et al., 2012]. Copper ions $\left(\mathrm{Cu}^{2+}\right)$ are toxic to most life forms. $\mathrm{Cu}$ is highly toxic to invertebrates and moderately so to mammals in trace amounts.

The results from the experimental measurements for the $\mathrm{Cu}^{2+}$ during the three seasons are shown in Table 2 and Figure 7. According to the Romanian standards for assessing the ecological status of surface water (GD161), the recommended value for the $\mathrm{Cu}^{2+}$ is $0.02->0.1 \mathrm{mg} / \mathrm{L}$. During the three-season study, the $\mathrm{Cu}^{2+}$ concentration varies from 0.0010 to $0.0380 \mathrm{mg} / \mathrm{L}$. The lowest value was measured at SP4 and SP5 stations in summer, whereas the highest value was measured at SP8 station in spring. The average values in spring, summer, and fall were 0.0210 ,
0.0050 , and $0.000 \mathrm{mg} / \mathrm{L}$ respectively, whereas the three-season average with the standard deviation was $0.0087 \pm 0.0070 \mathrm{mg} / \mathrm{L}$. The average concentrations of $\mathrm{Cu}^{2+}$ at SP1-SP8 stations were 0.0083, $0.0090,0.0137,0.0017,0.0017,0.0047,0.0043$, and $0.0140 \mathrm{mg} / \mathrm{L}$ respectively. In spring, the SP1 station showed the minimum value of 0.0050 $\mathrm{mg} / \mathrm{L}$, whereas SP7 station showed the maximum value of $0.0750 \mathrm{mg} / \mathrm{L}$. When compared to GD 161 standards, the obtained measured values were found to be under the detection levels at SP4 and SP6 stations. The water at SP1, SP2, SP5, and SP7 stations belonged to the first class, whereas the water at SP3 and SP8 stations belonged to the second class. In summer, the SP8 station showed the minimum value of $0.0110 \mathrm{mg} / \mathrm{L}$, whereas the SP1 station showed the maximum value of 0.0780 $\mathrm{mg} / \mathrm{L}$. During this season we detected only two values at two stations (SP4 and SP6) where the water belonged to the first class, whereas at all other stations, the values were under the detection levels. In fall, the SP5 station showed the minimum value of $0.0020 \mathrm{mg} / \mathrm{L}$, whereas the SP8 station showed the maximum value of $0.1680 \mathrm{mg} / \mathrm{L}$. In fall, the $\mathrm{Cu}^{2+}$ concentration values at each station were under the detection levels.

\section{Iron $\left(\mathrm{Fe}^{2+}\right)$}

$\mathrm{Fe}$ is an essential metal for most living organisms and humans. It is a constituent of proteins and many enzymes, including hemoglobin and myoglobin. $\mathrm{Fe}$ is usually more abundant in freshwater environment than other metals, due to its high occurrence on Earth [Forstner et al., 1979]. Fe deficiency can lead to anemia and fatigue, which are usually common among children under the age of five, pregnant women and

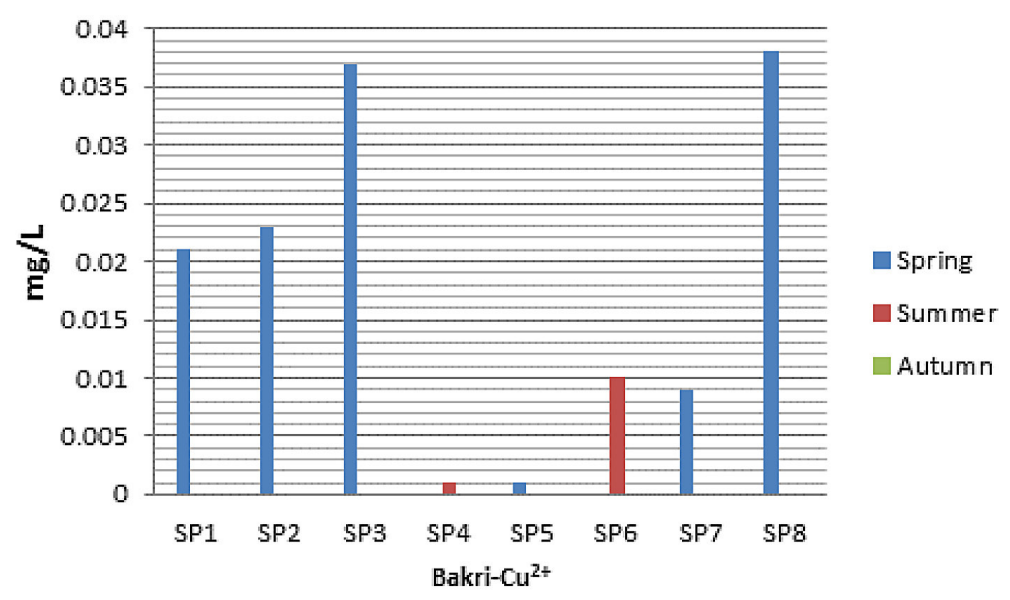

Figure 7. Variation of $\mathrm{Cu}$ values in water of Lepenci river 
immuno-compromised individuals, thus making them vulnerable to numerous infections [Garvin, 2015]. Vuori [1995] reported that Fe has both direct and indirect effects on river ecosystems, as it affects lotic organisms by interfering with their normal metabolism and osmoregulation. He also noted that the combined effects of Fe contamination can reduce the occurrence and diversity of several aquatic organisms, including fish. High $\mathrm{Fe}$ concentration, together with its precipitate in aquatic ecosystems, do have negative effects on the behavior, reproduction and survival of aquatic animals [Gerhardt, 1992]. Fe is an important metal for the life of plants and animals. The soluble $\mathrm{Fe}$ shares two of its electrons (oxidation state +2 ), whereas when reacting with oxygen, it forms a rusty-brown precipitate of iron hydroxide that is insoluble. In waters rich with $\mathrm{Fe}$, there is a bacterium known as "filamentous", which grows and multiplies. It has a highly negative impact on water quality, as it leads to the biomass collection in the distribution system. $\mathrm{Fe}$ is an essential metal of the hemoglobin structure and is used for the treatment of anemia, which is caused by the iron deficiency in the blood. It becomes toxic when used in large doses.

The results from experimental measurements for $\mathrm{Fe}^{2+}$ during the three seasons are presented in Table 2 and Figure 8. According to the Romanian standards for assessing the ecological status of surface waters (GD161), the recommended value for $\mathrm{Fe}^{2+}$ is $0.3->2 \mathrm{mg} / \mathrm{L}$. During the three-season study, the $\mathrm{Fe}^{2+}$ concentration varied from 0.0030 to $0.4010 \mathrm{mg} / \mathrm{L}$. The lowest value was measured at SP1 station in summer, whereas the highest value was measured at SP3 station in spring. The average values in spring, summer, and fall were $0.1920,0.1080$, and $0.1030 \mathrm{mg} / \mathrm{L}$ respectively, whereas the three-season average with the stan- dard deviation was $0.1343 \pm 0.0900 \mathrm{mg} / \mathrm{L}$. The average values of $\mathrm{Fe}^{2+}$ concentrations at SP1-SP8 stations were $0.0400,0.0507,0.1370,0.1650$, $0.1470,0.1227,0.1087$, and $0.1367 \mathrm{mg} / \mathrm{L}$ respectively. In spring, the SP7 station showed the minimum value of $0.0460 \mathrm{mg} / \mathrm{L}$, whereas the SP3 station showed the maximum value of 0.4010 $\mathrm{mg} / \mathrm{L}$. When compared to the GD 161 standards, the measured values resulted to be below detection levels at SP4 and SP6 stations. The water at SP1, SP2, SP5, and SP7 stations belonged to the first class, whereas the water at SP3 and SP8 stations belonged to the second class. In summer, the SP1 station showed the minimum value of $0.0030 \mathrm{mg} / \mathrm{L}$, whereas the water at SP4 station showed the maximum value of $0.0030 \mathrm{mg} / \mathrm{L}$. The values obtained at SP2, SP3, and SP8 stations were below detection levels. In fall, the SP3 station showed the minimum value of $0.0080 \mathrm{mg} / \mathrm{L}$, whereas the SP7 station showed the maximum value of $0.1990 \mathrm{mg} / \mathrm{L}$. In fall, the $\mathrm{Fe}^{2+}$ concentration values were below detection levels at all measuring stations. When compared to GD161 standard, the measured values at the three seasons resulted to be within the said standard, thus ranking the river water in the first class.

\section{Lead $\left(\mathrm{Pb}^{2+}\right)$}

$\mathrm{Pb}$ in the environment arises from both natural and anthropogenic sources. It is a natural constituent of air, water and biosphere. $\mathrm{Pb}$ is also a heavy metal that appears to be capable of +2 oxidation in aquatic environments and comes from various industrial sources and mines. $\mathrm{Pb}$ from gasoline (with tetraethyl lead), is the main source of atmospheric $\mathrm{Pb}$ and its large part passes in the water. Otherwise, it is rarely detected in natural waters. $\mathrm{Pb}$ is also a poisonous metal. In the case

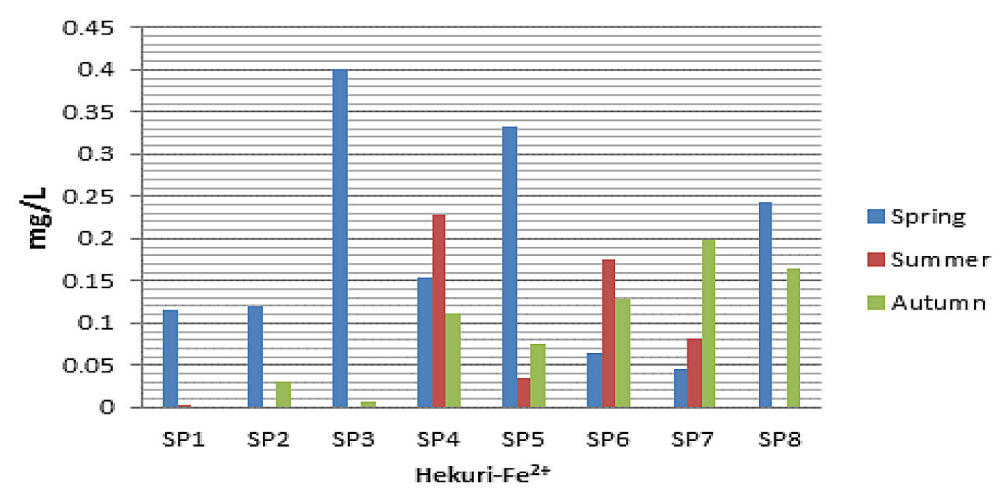

Figure 8. Variation of Fe values in water of Lepenci river 
of humans, the poisoning with $\mathrm{Pb}$ causes disturbances in the functioning of the kidneys, reproductive system, liver and nervous system. $\mathrm{Pb}$ poisoning caused by the environmental exposure causes mental retardation to more children, while mild poisoning leads to anemia. The lack of $\mathrm{Ca}$, $\mathrm{Fe}, \mathrm{Cu}, \mathrm{Se}$ and ascorbic acid in food conditions the accumulation of lead in the body. The largest amount of $\mathrm{Pb}$ accumulates is in the bones and it replaces $\mathrm{Ca}$. $\mathrm{Pb}$ organic compounds easily reach the human body through the skin and central nervous system at risk. The toxic effect of $\mathrm{Pb}$ is also based on the great affinity to sulfur. $\mathrm{Pb}$ reduces the activity of enzymes, oxidation-reduction reactions in the cell and protein synthesis. It is known that $\mathrm{Pb}$ poisoning is greater in hard waters than in soft waters. $\mathrm{Pb}$ is a serious cumulative body poison. High levels of exposure may result in biochemical effects in humans which in turn cause problems in the synthesis of haemoglobin, effects on the kidneys, gastrointestinal tract, joints and reproductive system, and acute or chronic damage to the nervous system [Tirkeyet al., 2012]. The sources include burning of lead based petroleum fuels, organic and inorganic lead compounds now used in a variety of commercial products and industrial materials including plastics, storage batteries, bearing alloys, insecticides, ceramics, cable sheathings, sheeting, radiation shields and even some paints [Mutwiri, 2001].

The measurements from experimental results for the $\mathrm{Pb}^{2+}$ during the three seasons are presented in Table 2 and Figure 9. According to the Romanian standards for the assessment of ecological status of surface waters (GD161), the recommended value for $\mathrm{Pb}^{2+}$ is $0.005->0.05$ $\mathrm{mg} / \mathrm{L}$. During the three-year study, the $\mathrm{Pb}^{2+}$ con- centration varied from 0.0000 to $0.0970 \mathrm{mg} / \mathrm{L}$. The lowest value was measured at SP1 - SP8 stations in summer, whereas the highest value was measured at SP8 station in fall. The average values in spring, summer, and fall were 0.2100 , 0.0000 , and $0.030 \mathrm{mg} / \mathrm{L}$ respectively, whereas the three-season average with the standard deviation was $0.0800 \pm 0.0452 \mathrm{mg} / \mathrm{L}$. The average values of $\mathrm{Pb}^{2+}$ concentrations at SP1-SP8 stations were $0.0170,0.0207,0.0030,0.0617,0.0020$, $0.1050,0.1247$, and $0.1613 \mathrm{mg} / \mathrm{L}$ respectively. The $\mathrm{Pb}$ values in the water of Lepenc river basin fluctuate from a minimum value of 0.0470 $\mathrm{mg} / \mathrm{L}$ (SP1) to a maximum value of $0.3850 \mathrm{mg} / \mathrm{L}$ (SP8) in the spring season. At two stations (SP3 and SP5) the values were below detection levels. In summer, the values of all monitoring stations were under the detection levels. In fall, the values ranged from a minimum of $0.005 \mathrm{mg} / \mathrm{L}$ (SP3) to a maximum of $0.097 \mathrm{mg} / \mathrm{L}$ (SP8). The values at SP1, SP4, and SP5 stations were below detection levels.

\section{Coefficients of correlation related to the concentration of metals of the river Lepenci}

The coefficients of correlation related to the concentration of waters in the Lepenci river were shown in Table 3. The results show that three values of coefficients of correlation appeared to be the most significant. $\mathrm{Pb}$ showed high a coefficient of correlation with $\mathrm{Zn}(r=0.8488)$, whereas $\mathrm{Fe}$ and $\mathrm{Cd}$ showed an average coefficient of correlation $(r=0.6678)$. A average negative coefficient of correlation was found between $\mathrm{Mn}$ and $\mathrm{Cr}(r=-0.6513)$ as well as between $\mathrm{Ni}$ and $\mathrm{Cr}$ $(r=-0.5277)$.

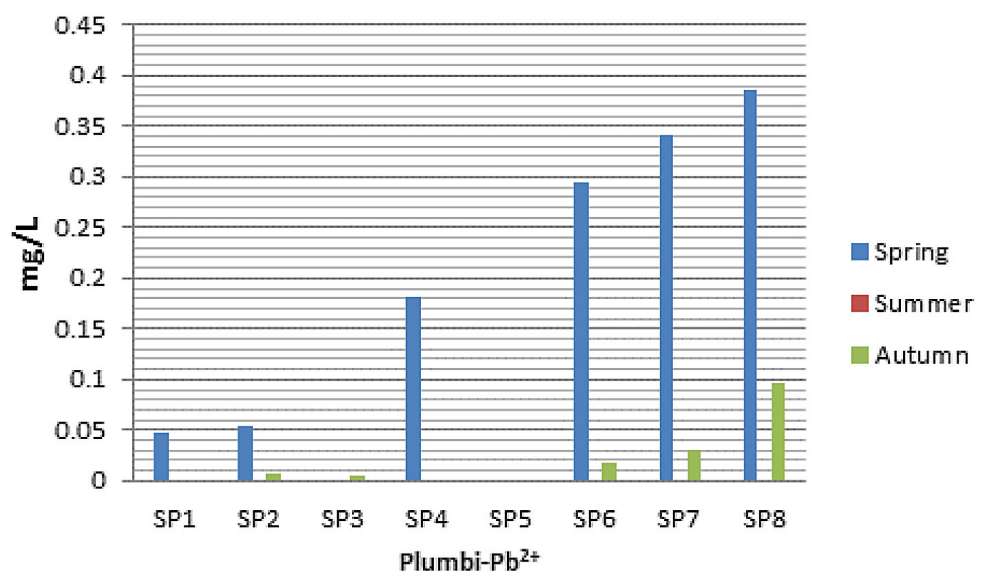

Figure 9. Variation of $\mathrm{Pb}$ values in water of Lepenci river 
Table 3. Coefficients of correlation for metal concentrations in the Lepenci River

\begin{tabular}{|c|c|c|c|c|c|c|c|c|}
\hline Correlation & $\mathrm{Cr}$ & $\mathrm{Cd}$ & $\mathrm{Ni}$ & $\mathrm{Zn}$ & $\mathrm{Mn}$ & $\mathrm{Cu}$ & $\mathrm{Fe}$ & $\mathrm{Pb}$ \\
\hline $\mathrm{Cr}$ & 1.0000 & & & & & & & \\
\hline $\mathrm{Cd}$ & 0.1866 & 1.0000 & & & & & & \\
\hline $\mathrm{Ni}$ & -0.5277 & 0.2196 & 1.0000 & & & & & \\
\hline $\mathrm{Zn}$ & 0.0763 & 0.1914 & -0.1559 & 1.0000 & & & & \\
\hline $\mathrm{Mn}$ & -0.6513 & -0.4941 & -0.0573 & -0.0885 & 1.0000 & & & \\
\hline $\mathrm{Cu}$ & 0.0749 & -0.1386 & -0.4500 & 0.3621 & 0.0966 & 1.0000 & & \\
\hline $\mathrm{Fe}$ & 0.2811 & 0.6678 & -0.1096 & -0.0662 & -0.3125 & -0.2320 & 1.0000 & \\
\hline $\mathrm{Pb}$ & -0.0399 & 0.5742 & 0.1257 & 0.8488 & -0.3152 & 0.0997 & 0.2511 & 1.0000 \\
\hline
\end{tabular}

\section{Water quality assessment of Lepenci River using WQI}

The calculation of Lepenci River Water Quality Index was done using the Water Quality Index Desktop software developed by [Ramadani et al., 2017]. The results for the factors F1, F2, and F3 and the WQI for the eight stations are given in Table 4, whereas the WQI values are graphically presented in Figure 10.

At SP1 station, the WQI value was found to be 80 , since two parameters ( $\mathrm{Cd}$ and $\mathrm{Mn}$ ) did not meet the recommended value of the regulation for assessment of river water quality, and two tests failed: $\mathrm{Cd}$ with a value of $0.0230 \mathrm{mg} / \mathrm{L}$ in summer and $\mathrm{Mn}$ with a value of $3.736 \mathrm{mg} / \mathrm{L}$ in fall. At SP2 station, the WQI value resulted to be 81 , since two parameters $(\mathrm{Cd}$ and $\mathrm{Pb})$ did not meet the recommended value of the regulation for assessment of river water quality, and two tests failed: $\mathrm{Cd}$ with a value of $0.0310 \mathrm{mg} / \mathrm{L}$ in summer and $\mathrm{Pb}$ with a value of $0.0530 \mathrm{mg} / \mathrm{L}$ in spring. At SP3 station, the WQI value was 75, since two parameters ( $\mathrm{Cd}$ and $\mathrm{Mn}$ ) did not meet the recommended value of the regulation, and three tests failed: $\mathrm{Cd}$ with a value of $0.0470 \mathrm{mg} / \mathrm{L}$ in summer, $\mathrm{Cd}$ with a value of $0.0150 \mathrm{mg} / \mathrm{L}$ in fall, and $\mathrm{Mn}$ with a value of $1.5020 \mathrm{mg} / \mathrm{L}$ in fall. At SP4 station, the WQI value was found to be 65 , since three parameters
$(\mathrm{Cd}, \mathrm{Mn}$, and $\mathrm{Pb})$ did not meet the recommended value of the regulation, and three tests failed: $\mathrm{Cd}$ with a value of $0.0840 \mathrm{mg} / \mathrm{L}$ in spring, Mn with a value of $1.6020 \mathrm{mg} / \mathrm{L}$ in fall, and $\mathrm{Pb}$ with a value of $0.1810 \mathrm{mg} / \mathrm{L}$ in spring. At SP5 station, the WQI value was 64 , since two parameters ( $\mathrm{Cd}$ and $\mathrm{Ni}$ ) did not meet the recommended value of the regulation, and four tests failed: $\mathrm{Cd}$ with a value of $0.0420 \mathrm{mg} / \mathrm{L}$ in spring, $\mathrm{Cd}$ with a value of 0.0750 $\mathrm{mg} / \mathrm{L}$ in summer, Cd with a value of $0.0330 \mathrm{mg} / \mathrm{L}$ in fall, and $\mathrm{Ni}$ with a value of $0.1180 \mathrm{mg} / \mathrm{L}$ in summer. At SP6 station, the WQI value amounted to 57 , since three parameters $(\mathrm{Cd}, \mathrm{Ni}$ and $\mathrm{Pb})$ did not meet the recommended value of the regulation, and five tests failed: $\mathrm{Cd}$ with a value of 0.1040 $\mathrm{mg} / \mathrm{L}$ in spring, Cd with a value of $0.0530 \mathrm{mg} / \mathrm{L}$ in summer, Cd with a value of $0.0090 \mathrm{mg} / \mathrm{L}$ in fall, and Pbwith a value of $0.2950 \mathrm{mg} / \mathrm{L}$ in spring. At SP7 station, the WQI value equalled 64, since three parameters $(\mathrm{Cd}, \mathrm{Ni}$ and $\mathrm{Pb})$ did not meet the recommended value of the regulation, and three tests failed: $\mathrm{Cd}$ with a value of $0.0820 \mathrm{mg} / \mathrm{L}$ in spring, Ni with a value of $0.1190 \mathrm{mg} / \mathrm{L}$ in spring, and $\mathrm{Pb}$ with a value of $0.3410 \mathrm{mg} / \mathrm{L}$ in spring. At SP8 station, the WQI value was 59, since two parameters $(\mathrm{Cd}$ and $\mathrm{Pb})$ did not meet the recommended value of the regulation, and four tests failed: Cd with a value of $0.0890 \mathrm{mg} / \mathrm{L}$ in spring, $\mathrm{Cd}$ with a value of $0.0840 \mathrm{mg} / \mathrm{L}$ in summer; $\mathrm{Pb}$

Table 4. Values obtained from the Water Quality Desktop and WQI calculation

\begin{tabular}{|c|c|c|c|c|}
\hline Stations & $\mathrm{F} 1$ & $\mathrm{~F} 2$ & F3 & WQI \\
\hline SP1- Prevallë & 25 & 8.333334 & 20.88608 & 80 \\
\hline SP2- Jezerc & 25 & 8.333334 & 17.97676 & 81 \\
\hline SP3-Brodë & 25 & 12.5 & 31.23603 & 75 \\
\hline SP4-Runjevë & 37.5 & 12.5 & 44.21459 & 65 \\
\hline SP5-Nikë & 25 & 16.66667 & 53.10668 & 64 \\
\hline SP6-Gërlicë & 37.5 & 20.83333 & 59.76530 & 57 \\
\hline SP7-Kaçanik & 37.5 & 12.5 & 47.1482 & 64 \\
\hline SP8-Hani iElezit & 25 & 16.66667 & 62.6401 & 59 \\
\hline & & & Average WQI: & 68.1250 \\
\hline
\end{tabular}




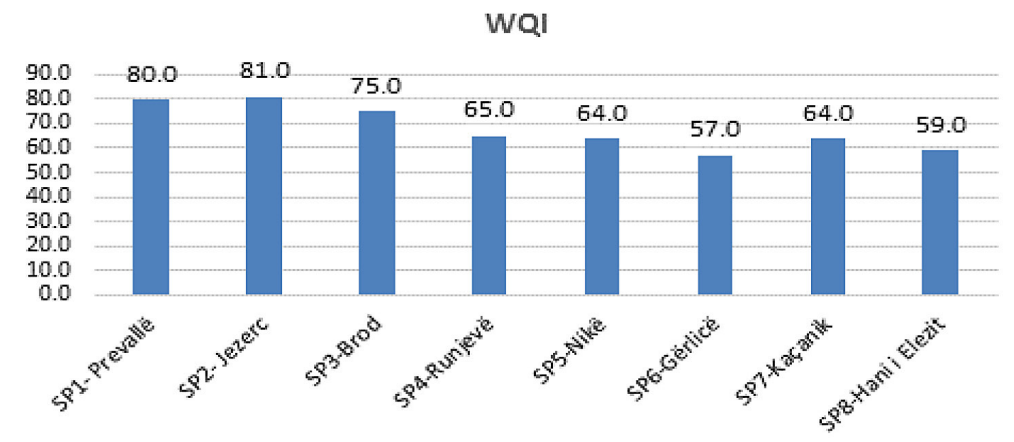

Fig. 10. WQI values at all measuring stations

with a value of $0.3850 \mathrm{mg} / \mathrm{L}$ in spring, and $\mathrm{Pb}$ with a value of $0.0970 \mathrm{mg} / \mathrm{L}$ in fall.

The results show that the river water at SP2 station had the best quality with a WQI value of 81 and belonged to the good category, whereas the river water at SP6 station had the worst quality with a WQI value of 57 and belonged to marginal category. Finally, based on these results, the average WQI value was calculated for the entire measurement period and it resulted to be 68.1250 which showed that the water of Lepenc River belonged to fair category.

\section{CONCLUSIONS}

Given the research conducted and the discussion of results we can draw the following conclusions:

1. Although Lepenci, being a mountain river, has a self-cleaning capability for its waters, slight heavy metals pollution was observed during the monitoring period;

2. Water pollution of Lepenci River with heavy metals assessed by the Romanian standards for the assessment of ecological status of surface waters (GD161) was low and the most severe heavy metals pollution was observed at the stations located at the bottom of the river;

3. During the monitoring period the water of Lepenci River was categorized in second-third class;

4. The sequence of average values with standard deviation of heavy metals concentrations in the water of Lepenc river expressed in $\mathrm{mg} / \mathrm{L}$ was as follows: $\mathrm{Mn}(0.5133 \pm 0.5067)$

$>\mathrm{Fe}(0.1343 \pm 0.0900)>\mathrm{Pb}(0.0800 \pm 0.0452)$

$>\mathrm{Ni}(0.0527 \pm 0.0370)>\mathrm{Cd}(0.0487 \pm 0.0193)$

$>\mathrm{Zn}(0.0387 \pm 0.0360)>\mathrm{Cr}(0.0233 \pm 0.005)>$ $\mathrm{Cu}(0.0087 \pm 0.0070)$;
5. Calculation of coefficients of correlation showed that it was the highest between $\mathrm{Pb}$ and $\mathrm{Zn}(\mathrm{r}=0.8488)$, average between $\mathrm{Fe}$ and $\mathrm{Cd}(\mathrm{r}=0.6678)$, and negatively average between $\mathrm{Mn}$ and $\mathrm{Cr}(\mathrm{r}=-0.6513)$ and between $\mathrm{Ni}$ and $\mathrm{Cr}(\mathrm{r}=-0.5277)$;

6. The Water Quality Index Desktop software was also used as a highly efficient tool for WQI calculation based on the guidelines of the $\mathrm{Ca}$ nadian Ministry of Environment;

7. On the basis of the WQI calculation using the Water Quality Index Desktop software, it was found that the river water at the SP2 station had the best water quality with a WQI value of 81 (the category: good), river water at SP6 station had the worst quality with a WQI value of 57 (category: marginal), whereas the average WQI for the entire measurement period was 68.1250 (category: fair);

8. Water Quality Index Desktop software has provided excellent and reasonable results;

9. We propose that the state authorities and institutions should support river water monitoring as an effective measure for examining their ecological status and protection against various types of pollution.

\section{REFERENECES}

1. Anderson D. 2003. Introduction to heavy metal monitoring centre for ecology and hydrology, Natural Environment Research Council, 13th October.

2. Bakare A.A., Lateef A., Amunda O.S., Afulabi R.O. 2003. The aquatic toxicity and characterization of chemical and microbiological constituents of water samples from Oba River, Odo-Oba, Nigeria. Asian J. Microbiol. Biotechnol. Environ. Science, 5, 11-17.

3. BožoDalmacija - Editor. 2001. Kontrola kvaliteta voda, Univerzitet u Novom Sadu, Insitut za 
Hemiju, Kadetra za hemijsku tehnologiju i zaštitu životne sredine, 15-17, 253.

4. Bradi B.H. 2005. Heavy metals in the environment. In: Interface Science and Technology. Hubbard A. (Ed.), Vol. 6, Elsevier Academic Press, Neubrucke.

5. CCME. 2001. Canadian water quality guidelines for the protection of aquatic life: CCME Water Quality Index 1.0 User's Manual. Canadian Council of Ministers of the Environment.

6. City Kaçanik.2011. Municipality of Development Plan.

7. Damodharan U. 2013. Bioaccumulation of heavy metals in contaminated river water - Uppanar, Cuddalore South East Coast of India. htt//.dx.doi. org/10.5772/5334.

8. Diagomanol I.N.V., Farhang M., Ghazi-Khansari M., Jafarzadeh N. 2004. Heavy metals (Ni, Cr, Cu) in the Karoon waterway river, Iran. Toxicol. Lett., 151(1), 63.

9. Durmishi B.H., Abduli S., Reka A.A., Ismaili M., Shabani A., Durmishi A. 2016. Determination of the Content of $\mathrm{Zn}, \mathrm{Cu}, \mathrm{Pb}$ and $\mathrm{Cd}$ in the River Shkumbini (Pena) with Potentiometric Stripping Analysis. International Journal of Chemistry \& Materials Sciences, 1(1), 17-32.

10. Durmishi B.H., Ismaili M., Shabani A., Abduli S. 2012. Drinking Water Quality Assessment in Tetova Region. American Journal of Environmental Sciences, 8(2), 162-169.

11. Duruibe J.O., Ogwuegbu M. C., Egwurugwu J.N. 2007. Heavy metal pollution and human biotoxic effects. International Journal of Physical Sciences, 2, 112-118.

12. Forstner U., Wittmann G.T.W. 1979. Metal Pollution in the Aquatic Environment. Springer-Verlag, Berlin, Germany.

13. Garvin K.S. 2019. Health Effects of Fe in Drinking Water. Available online: http://www.livestrong. com/article/155098-health-effects-of-iron-indrinking-water (accessed on 24 November 2015).

14. Gerhardt A. 1992. Subacute effects of iron (Fe) on Leptophlebiamarginata (Insecta: Ephemeroptera). Freshwater Biol., 27, 79-84.

15. Kitaura H., Nakao N., Yoshida N., Yamada T. 2003. Induced sensitization to nickel in guinea pigs immunized with mycobacteria by injection of purified protein derivative with nickel. New Microbiol., 26(1), 101.

16. Krishna P.V., Rao K.M., Swaruparani V., Rao D.S. 2014. Heavy metal concentrations in Fish Mugilcephalus from Machilipatnam Coast and possiible health risks to fish consumers. British Biotechnology Journal, 4(2), 126-135.

17. Kumar B., Mukherjee D.P., Kumar S., Mishra M., Prakash D., Sigh S.K., Sharma C.S. 2011. Bioaccumulation of heavy metals in muscle tissue of fisheries from selected aquaculture ponds in east Kolkata etlands. Annals of Biological Research, 2(5). 125-134.

18. MESP 2010.The state of water report in Kosova. Prishtina.

19. Mutwiri N.M. 2001. Determination of cadmium, chromium, lead and mercury in honey samples from Mbeere, Meru and Kirinyaga districts unpublished, MSc Thesis, Chemistry Department, Egerton University, Nakuru, Kenya.

20. Ndimele P.E. 2008. Evaluation of phyto-remediative properties of water hyacinth (Eichhorniacrasspies) and biostimulants in restoration of oilpolluted wetland in the Niger Delta. PhD Thesis, University of Ibadan, Nigeria.

21. Rajappa B., Manjappa S., Puttaiah E.T. 2010. Monitoring of Heavy metal in groundwater of Hakinaka Taluk, India. Contemporary Engineering Sciences, 3(4), 183-190.

22. Ramadani E., Memeti A., Durmishi B.H. 2017. Water Quality Index: A New Automated Way of Measuring the Quality. International Journal on Information Technologies \& Security, 3, 43-52.

23. Scott-Fordsmand J.J. 1997. Toxicity of nickel to soil organisms in Denmark. Rev. Environ. Contam. Toxicol., 148, 1.

24. Senarathne P. and Pathiratne K.A.S. 2007. Accumulation of heavy metals in a food fish, Mystusgulio in habiting Bolgoda Lake, Sri Lanka. Sri Lanka J. Aquat. Sci., 12, 61-75.

25. Suresh, B., Steiner W., Rydlo M., Taraschewski H. 1999. Concentrations of 17 elements in Zebra mussel (Dreissena polymorpha). Environmental Toxicology and Chemistry, 18, 2574-9.

26. Tirkey A., Shrivastava P., Saxena A. 2012. Bioaccumulation of heavy metals in different components of two Lakes ecosystem. Current World Environment, 7(2), 293-297.

27. Vuori K.M. 1995. Direct and indirect effects of iron on river ecosystems. Ann. Zool. Fennici., 32, 317-329.

28. WHO. 2000. Hazardous Chemicals in human and environmental health, WHO, Gineva, Switzerland.

29. WHO. 2011. Guidelines for drinking water quality, 4th edn. World Health Organization, Geneva, 2011, pp. 564 . 